\title{
KONTRAK SEBAGAI SARANA MEWUJUDKAN KESEJAHTERAKAN SOSIAL
}

\author{
(Contract as Means to Create Social Welfare)
}

\author{
Zulfirman \\ Magister ilmu Hukum Universitas Pembinaan Masyarakat Indonesia, \\ Jalan Teladan No. 11-15 Medan, 20217 \\ Email: zulfirman13@yahoo.com
}

Naskah diterima: 16 Agustus 2017; revisi: 10 November 2017; disetujui: 15 November 2017

\begin{abstract}
Abstrak
Kontrak dilahirkan atas dasar kebebasan manusia sebagai implementasi hak asasi manusia. Prinsip kebebasan berkontrak dalam hukum kontrak berasal dari paham individualis melahirkan politik ekonomi pasar bebas untuk mengejar kesejahteraan individu. Penerapan prinsip kebebasan berkontrak menjadi permasalahan bagi negara Indonesia sebagai negara kesejahteraan, apakah daya laku kebebasan berkontrak sebagai hak asasi manusia digerakkan untuk mencapai kesejahteraan sosial atau kesejahteraan individu. Artikel ini adalah studi yuridis normatif analitis suatu studi kepustakaan. Data yang dipergunakan adalah data skunder meliputi bahan hukum primer, sekunder dan tertier. Data dianalisis secara kualitatif menggunakan metode hermeneutik hukum melalui pendekatan filsafat. Indonesia memandang kebebasan berkontrak sebagai sarana mewujudkan kesejahteraan sosial dan memandang kontrak dari sisi kemasyarakatannya ditafsirkan secara objektif, berbeda dari paham individualis menafsirkan kontrak secara subjektif. Kebebasan berkontrak dalam dunia bisnis dioperasionalisasikan untuk terciptanya keenakan hidup yang pantas yang menampakan dirinya pada kesejahteraan sosial dengan tetap menghormati kesejahteraan individu. Untuk kebutuhan praktis, perlu dilakukan sosialisasi kepada praktisi hukum dan ekonomi mengenai tafsir daya laku prinsip kebebasan berkontrak.
\end{abstract}

Kata Kunci: kontrak, kebebasan berkontrak, kesejahteraan masyarakat

\begin{abstract}
Contract was born on the basis of human freedom as the implementation of human rights. The principle of freedom of contract in contract law stems from the individualist understanding of free market economy politics to pursue the welfare of the individual. Implementation of the principle of freedom of contract becomes a problem for Indonesia as a welfare state, whether the freedom of contracting power as a human right is mobilized to achieve social welfare or individual welfare. This article is an analytical normative juridical study of a literature study. The data used are secondary data covering primary, secondary and tertiary legal materials. Data were analyzed qualitatively using the hermeneutic method of law through philosophical approach. Indonesia views the freedom of contract as means of creating social welfare and sees the contract from its social side interpreted objectively, unlike the individualist understanding of the contract subjectively. The freedom of contract in the business world is operationalized for the creation of a decent life-style that presents itself to social welfare by respecting the well-being of individuals. For practical needs, it is necessary to socialize legal and economic practitioners on the interpretation of the principle of freedom of contract.
\end{abstract}

Keywords: contract, freedom of contract, social welfare 


\section{A. Pendahuluan}

Dalam kehidupan sosial terdapat tiga sektor yang saling mengkait satu sama lainnya yaitu pemerintah, pengusaha dan masyarakat sipil. ${ }^{1}$ Ketiga sektor masyarakat itu selalu dan tidak dapat melepaskan diri dari kontrak sebagai suatu keniscayaan yang menjadi sarana penting sendi kehidupan masyarakat manusia, karena melaluinya manusia baik secara individual maupun kolektif dapat mengembangkan kualitas hidupnya.

Kontrak sebagai sarana kehidupan individu maupun sosial banyak dioperasionalkan setiap hari di seluruh dunia, dan menjadi penting dilakukan dalam kegiatan dunia bisnis; dengan kontrak perusahaan-perusahaan, individuindividu, dan pemerintah dapat berinterkasi satu sama lainnya dengan cara membuat aturanaturan yang jelas dalam interaksi tersebut. ${ }^{2}$ Kontrak itu sendiri pada dasarnya adalah implementasi kebebasan suatu hak yang dimiliki setiap manusia karena ia adalah manusia. Dalam persepsi kenegaraan, kebebasan itu sering diungkapkan sebagai kebebasan sipil yang secara khusus merujuk pada apa yang disebut dengan Hak Asasi Manusia (HAM). ${ }^{3}$

Kebebasan sipil sebagai hak mengarah pada dua jalur. Pertama, kebebasan sipil sebagai hak politik. Kedua, kebebasan sipil sebagai hak sipil (privat). Hak yang disebutkan terakhir berkenaan dengan hak individu atau pribadi terkait dengan pertukaran kekayaan untuk memenuhi kesejahteraan pribadi. Sifat hak ini tidak memiliki kekuasaan politik (pemerintahan). Hak yang disebutkan pertama, berkenaan dengan pengalihan hak individu menjadi hak kolektif yang melahirkan bentuk figur entitas baru sebagai identitas bersama yang disebut negara. Entitas ini memiliki kewenangan mengatur dan menata kehidupan sosial yang memiliki ciri kekuasaan politik atau pemerintahan negara.

Kebebasan sipil sebagai hak privat sebagai cerminan konsep manusia makhluk individu, sedangkan kebebasan sipil sebagai hak politik sebagai cerminan konsep manusia makhluk sosial. Kedua bentuk kebebasan tersebut mempunyai titik temu yang sama, yaitu mewujudkan kesejahteraan. Kesejahteraan itu sendiri merupakan domain kajian ekonomi dan hukum; sarana menggapainya adalah kontrak.

Pembicaraan kontrak dalam pandangan kesejahteraan sosial dari kacamata kekuasaan negara berkaitan dengan kebijakan politik dan hukum ekonomi, sedangkan dari kacamata privat dalam pandangan kesejahteraan individu merupakan domain otonomi individu (privat) yang bebas dari kekuasaan politik. Dua aspek pandangan itu menimbulkan konsekuensi perbedaan pemahaman terhadap daya laku kebebasan membuat kontrak.

Kontrak dalam kaitannya dengan
kesejahteraan sosial titik berat kajiannya
berbicara kebijakan politik dan hukum tentang ekonomi pemerintahan, yaitu berkaitan dengan cara pandang pemerintah terhadap kebebasan berkontrak. Hal itu berpengaruh

IK. Rai Setiabudhi, "Peranan Masyarakat Sipil dalam Pemberantan Korupsi: Model Pencegahan dari Bali” dalam Jurfrina Rizal dan Suhariyiono AR (ed), Demi Keadilan Antologi Hukum Pidana Dan Sistem Peradilan Pidana, (Jakarta: Pustakan Kemang, 2016), hlm. 145.

2 Mohd Ma'sum Billah, Islamic E-Comerce Terapan, Tinjauan Hukum dan Praktek, terjemahan Ahmad Dumyathi Bashori, (Petaling Jaya, Selangor, Malaysia: Sweet \& Maxwell Asia, 2010), hlm. 171.

3 Tom Head, "Civil Liberty", http://civilliberty.about.com/od/internastionalhumanrights/g/ Human-Right (diakses 1 Juli 2017). 
terhadap pengaturannya dan kebijakan yang diambil terhadapnya. Jika pemerintah (negara) memandang kebebasan berkontrak sebagai sarana mewujudkan kesejahteraan sosial maka daya laku kebebasan berkontrak mendapat kontrol dan dapat dibatasi demi tujuan umum, sebaliknya jika pemerintah memandang kebebasan berkontrak sepenuhnya ditujukan sebagai sarana mengejar kesejahteraan individu (pribadi), maka kebebasan berkontrak tidak perlu ada kontrol pemerintah dan memberi keluasan bagi individu untuk mengoperasionalisasikannya.

Dua masalah krusial di atas dihadapi oleh pemerintahan Indonesia sebagai negara kesejahteraan, sebagaimana diamanahkan dalam Pembukaan UUD 1945 yang menyatakan : “...membentuk suatu Pemerintahan Negara Indonesia yang melindungi segenap bangsa Indonesia dan seluruh tumpah darah Indonesia dan untuk memajukan kesejahteraan umum,..." Dari frasa ini terlihat tugas pemerintah negara Indonesia adalah menciptakan kesejahteraan sosial, di mana pemerintah negara Indonesia bertindak aktip dalam lapangan ekonomi demi terwujudnya kesejahteraan umum. Konsekuensinya, pemerintah dapat campur tangan terhadap kebebasan berkontrak sebagai hak sipil manusia individu. Dari pernyataan ini, terdapat beberapa masalah yang akan dikaji dalam artikel ini: Pertama, bagaimana kebebasan sebagai HAM diimplementasikan dalam hukum kontrak Indonesia; Kedua, bagaimana hubungan kebebasan berkontrak dengan kesejahteraan manusia; Ketiga, bagaimana negara memperlakukan daya laku asas kebebasan berkontrak dalam hubungannya mewujudkan kesejahteraan individu dan kesejahteraan bersama (sosial) di Indonesia.

\section{B. Metode Penelitian}

Tulisan ini merupakan suatu penelitian kepustakaan dalam lingkup penelitian yuridis normatif analitik, suatu penelitian yang didasarkan pada pemikiran kritis terhadap norma undang-undang khususnya tentang kebebasan berkontrak sebagai prinsip utama hukum kontrak. Penelitian ini mencoba mengungkapkan secara mendasar tentang makna kebebasan berkontrak sebagai dasar pembentukan norma hukum dalam lalu lintas hubungan perseorangan dan perlakuan negara atau pemerintah terhadapnya, dalam upaya pemerintah negara menjalankan fungsinya mewujudkan kesejahteraan sosial.

Penelitian ini menggunakan data skunder yang diperloleh melalui studi kepustakaan. Data sekunder yang dipergunakan meliputi bahan hukum primer yakni UUD RI 1945, The Universal Declaration of Human Rights 1948, KUHPerdata stb 1847-23 diundangkan tanggal 30 April 1847, Undang-Undang Nomor 12 Tahun 2005 tentang Pengesahan Kovenan Internasional Hak sipil dan Politik, Undang - undang Nomor 8 Tahun 1999 Tentang Perlindungan Konsumen (UUPK), Undang-undang Nomor 9 Tahun 1999 Tentang Larangan Praktek Monopoli dan Persaingan Usaha Tidak Sehat (UU Anti Monopoli), dan Undang-undang Nomor 39 Tahun 1999 tentang Hak Asasi Manusia (UU HAM). Data sekunder lainnya berupa bahan hukum sekunder berupa pendapat para ahli yang termuat di dalam literatur buku, jurnal dan makalah yang termuat dalam bentuk cetak maupun elektronik. Untuk penguatan pengertian terhadap istilah-istilah hukum dipergunakan bahan hukum tertier berupa kamus hukum dan ensiklopedi hukum.

Analisis pembahasan dalam tulisan ini dilakukan melalui pendekatan filosofis normatif terkait hukum kontrak. Data yang diperoleh 
dianalisis secara kualitatif dengan memfokuskan pada makna isi dari data yang ada. Untuk memperoleh makna isi dari data, dipergunakan metode penafsiran atau hermeneutik hukum guna mengeksplor makna yang tersirat di dalam ketentuan undang-undang tentang kebebasan berkontrak dan dasar pemikiran yang terkandung didalamnya. Hasil penafsiran dijadikan acuan untuk menggambil kesimpulan guna menjawab permasalahan yang telah ditetapkan.

\section{Pembahasan}

\section{Kontrak sebagai Implementasi HAM}

Manusia adalah makhluk yang paling sempurna di dunia ini. Kesempurnaan manusia dapat dipahami karena ia memiliki akal dan kehendak. Manusia dengan akalnya dapat melakukan penilaian, penjelasan dan pilihan. Oleh karenanya manusia, secara kodrati, memiliki hak fundamental yaitu kebebasan, hak hidup, dan keamanan pribadi. ${ }^{4}$ Hak fundamental itu pada prinsipnya terpusat pada manusia. Hak itu merupakan bagian dari hukum positif adalah prinsip hukum yang telah diterapkan dalam undang-undang, sering dirumuskan secara luas, yang merupakan bagian dari konstitusi nasional atau perjanjian HAM internasional. ${ }^{5}$

Dalam realitas kehidupan manusia, hak fundamental itu saling berinteraksi antara manusia yang satu dengan manusia lainnya; salah satunya dalam wujud kontrak. Chantal Mak menerangkan kontrak mengandung hak fundamental manusia dapat dilihat dari dua kriteria: Pertama, dilihat dari sisi formal; Kedua, dari sisi substansi. Secara formal suatu hak fundamental adalah hak yang ditentukan dalam ketentuan konstitusi, sedangkan secara substansi hak adalah norma yang bertujuan untuk menjamin martabat manusia atau hak yang mendasar bagi perlindungan otonomi pribadi. ${ }^{6}$ Kebebasan berkontrak adalah hak dasar seorang individu untuk masuk ke dalam perjanjian Itu memperoleh atau menyerahkan harta, jasa atau mengubah hubungan hukum. ${ }^{7}$

Kontrak sebagai HAM merupakan pendapat klasik sebagaimana yang dikemukakan oleh Grotius bahwa hak untuk mengadakan kontrak adalah salah satu HAM. Pada sisi lain, Thomas Hobbes menerangkan setiap individu diberdayakan untuk menikmati kebebasannya mereka secara bebas tanpa gangguan orang lain sebagai hak dasar yang diperolehnya melalui alam yang melalui kontrak hak itu dapat dipertukarkan. ${ }^{8}$

Kontrak sebagai sarana mengimplementasikan hak fundamental terlihat dari tiga hal. Pertama, kontrak dibangun atas dasar kebebasan yang dimiliki oleh manusia. Rosseau berpandangan kebebasan manusia itu berasal dari alam karena itu manusia harus bebas membangun setiap hubungan

Lihat Artickle 3 The Universal Declaration of Human Rights 1948; "everyone has the right to life, liberty and security of person.

5 H. Patrick Glenn, Legal Traditions of The The World Sustsainable Diversity in Law, (Oxport : Oxport University Press, 2000), hlm. 131.

6 Zulfirman, Hak Dasar Manusia Dalam Kontrak dan Perlindungannya di Indonesia, (Malang: Intelegensia Media, 2017), hlm. 274.

7 David P. Weber, "Restricting the Freedom of Contract: A Fundamental Prohibition," Yale Human Rights and Development Journal: Vol. 16: Iss. 1, Article 2 (2-18-2014) : 56.

$8 \quad$ Zufirman, op.cit., hlm. 99 
hukum. ${ }^{9}$ Kebebasan itu sendiri sebagai bentuk kemampuan untuk berkeinginan, memilih, memutuskan atau sebagai tidak ada gangguan dari luar. Peran dan fungsi kebebasan berkontrak berasal dari gagasan nilai universal yang menyusupi prinsip dan konsep hukum "otonomi" atau "otonom" sebagai inti dari nilainilai ini. ${ }^{10}$ Dalam hukum kontrak, kebebasan menjadi prinsip utama dan ini berlaku pada semua sistem hukum yang ada di dunia. Prinsip itu disebut dengan istilah freedom of contract atau kebebasan berkontrak. ${ }^{11}$

Kedua, kontrak dibangun sebagai bentuk pertukaran kekayaan. Kontrak sebagai bentuk pertukaran yang saling menguntungkan telah diterima sejak peradaban manusia yang amat sederhana yang terus berevolusi kearah memperluas kebebasan. ${ }^{12}$ J.H. Niewenhuis sebagaimana dikutip Agus Yudha Hernoko menyebutkan rasio kontrak beranjak dari tujuan terjadinya tukar menukar harta kekayaan yang adil. ${ }^{13}$ Kontrak adalah kemampuan seseorang untuk mewajibkan dirinya dalam pertukaran kewajiban sesama lainnya. ${ }^{14}$ Kontrak sebagai bentuk pertukaran adalah gagasan kerjasama antar umat manusia. ${ }^{15}$

Ketiga, kontrak dilahirkan untuk membangun kualitas hidup manusia. Hal itu berhubungan erat dengan kepemilikan. Catarine Krause berpendapat hak kepemilikan berkenaan dengan standar hidup yang layak dan hidup yang bermartabat bagi setiap orang. ${ }^{16}$ Oleh karena itu, seperti Hugh Collin menyebutkan, kontrak tidak hanya diakui sebagai cara mendistribusikan kekayaan, dan membangun kekuatan hubungan, tetapi yang paling penting memberi kesempatan untuk merealisasikan makna kehidupan para pihak sebagai manusia yang berhak hidup. ${ }^{17}$

Dari apa yang diterangkan di atas, tepatlah apa yang diungkapkan P.S. Atiyah sebagaimana dikutip Agus Yudha Hernoko yang menerangkan kontrak memilik tiga tujuan. Pertama, kontrak wajib untuk dilaksanakan (memaksa) serta memberikan perlindungan terhadap suatu harapan yang wajar. Kedua, kontrak berupaya mencegah terjadinya suatu penambahan kekayaan secara tidak adil. Ketiga, kontrak

9 Irena Lavdari, "The Contractual Freedom as an Essential Condition for the Existence of the Contract in a Global Economy", Mediterranean Journal of Social Sciences, Vol. 4 No. 11 (October 2013) : 430.

10 Hans-W. Micklitz, "On the Intellectual History of Freedom of Contract and Regulation", Penn State Journal of Law \& International Affairs, Vol. 4 Issue 1 (Desember 2015) : 14.

11 Moch, Insaeni, Perkembangan Hukum Perdata di Indonesia, (Yogyakarta : Laksbang Grafika, 2013) hlm. 10. Lihat Rinduan Khairandy, Iktikad baik dalam Kebebasan Berkontrak, Uakarta: Universitas Indonesia, Pascasarjana, 2003), hlm. 27. Lihat juga Soejono Dirdjosisworo, Misteri dibalik Kontrak Bermasalah, (Bandung: Mandar Maju, 2002), hlm. 14. Lihat lagi Hugh Collin, "The Impact of Human Rights Law on Contract Law in Europe, University of Cambridge Faculty of Law Legal Studies, Paper, No. 13, (2011) : 5.

12 Adam J. Hirsch, "Freedom of Testation / Freedom of Contract", Minnesota Law Review, Article 95. 2180, (2011): 2189.

13 Moch. Isnaeni, op.cit., hlm. 38.

14 David P. Weber, op.cit., : 51.

15 Karen Leback, Six Theorities of Justice, terjemahan Yudi Santoso, (Bandung: Nusa Media, 2012), hlm. 6.

16 Ifdal Kasim dan Johannes de Masenus Arus (ed), Hak Ekonomi, Sosial, Budaya Essai-essai pilihan, terjemahan elsam, (Jakarta: Elsam, 2012), hlm. 139.

17 Luanda Howthome, "Contitution and Contract: "Human Digty, The Theory Capabilities and Existenzgrundlage in South Africa", Journal Studia Law Universitas Babes-Bolyai, No. 2, (2011), http:??studia.law.ubbluj,ro/articol. php?articolId=433 (diakses 23 Juni 2017). 
bertujuan untuk mencegah terjadinya kerugian tertentu dalam hubungan kontraktual. ${ }^{18}$

Tiga hal yang berhubungan dengan kontrak tersebut di atas sesungguhnya melukiskan hak sipil manusia yang dalam hukum kontrak Indonesia dapat dipahami melalui Pasal 1, Pasal 2, dan Pasal 3 KUHPerdata. ${ }^{19}$ Tiga ketentuan pasal tersebut sebagai poros utama hak sipil, yang salah satu penjabarannya dituangkan dalam Buku III KUHPerdata tentang perikatan. Hemat penulis, bila diperiksa secara cermat dan kritis, tiga poros utama hak sipil dalam KUHPerdata tersebut indentik dengan norma hukum HAM Internasional sebagaimana termuat pada Article 3 The Universal Declaration of Human Rights 1948 (UDHR): "everyone has the right to life, liberty and security of person". Penulis berkeyakinan, ketentuan yang termuat dalam KUHPerdata termasuk hukum kontrak yang diatur di dalamnya, pada dasarnya bentuk implementasi hak sipil individu atau HAM melalui undang-undang. Tujuannya tidak lain agar hak sipil sebagai HAM mendapat jaminan perlindungan, penghormatan, dan pemenuhan yang memadai dalam pergaulan perseorangan di tengah-tengah masyarakat yang diarahkan pada peningkatan dan pengembangan kualitas hidup manusia.

Collins belajar dari perkembangan sejumlah yuridiksi Eropa menerangkan tiga hal yang
signifikanmempengaruhidampakHAMterhadap hukum kontrak di Eropa. Pertama, berkaitan dengan konsepsi kebebasan berkontrak yang didukung oleh hak konstitusi. Kedua, hak yang dianggap cukup mendasar untuk mengarahkan kekuatan pada evolusi hukum kontrak. Ketiga, berhubungan dengan pengengambangan mekanisme yang menyeimbangkan guna menyesuaikan dengan hukum privat. Hal ini disebabkan dampak ketentuan HAM, khususnya hukum kontrak yang dibuat oleh individu pihak sipil bervariasi sesuai dengan pemahaman pendapat antara pengadilan dan praktisi hukum (pengacara). ${ }^{20}$

\section{Asas Kebebasan berkontrak dan kesejahteraan manusia}

Bangunan hukum kontrak pada umumnya, termasuk hukum kontrak Indonesia, disangga oleh prinsip kebebasan berkontrak yang ditopang dengan prinsip konsensualisme dan prinsip kekuatan mengikat perjanjian. Dalam hukum kontrak Indonesia hal itu dapat ditemui pada Pasal 1338 KUHPerdata yang mengatakan : "semua perjanjian yang dibuat secara sah berlaku sebagai undang-undang bagi yang membuatnya. Perjanjian itu tidak dapat ditarik kembali selain dengan kesepakatan kedua belah pihak, atau karena alasan-alasan yang

\footnotetext{
Moch, Isnaeni, op.cit, hlm. 54.

19 Pasal 1 KUHPerdata : "menikmati hak keperdataan tidak tergantung pada hak negara". Makna norma ini adalah kebebasan manusia, Pasal 2 KUHPerdata : "anak dalam kandungan dianggap telah dilahirkan apabila kepentingan menghendakinya". Makna norma ini adalah hak hidup dan milik individu; Pasal 3 KUHPerdata : "tidak ada satu hukumanpun yang menghilangkan hak keperdataan seseorang". Makna norma ini terkait dengan keamanan pribadi. Bandingkan dengan Pasal 3 ayat (3) UU No. 39 Tahun 1999 tentang HAM : Setiap orang berhak atas perlindungan hak asasi manusia dan kebebasan dasar manusia, tanpa diskriminasi, Pasal 9 ayat (1) UU tengang HAM : Setiap orang berhak untuk hidup, mempertahankan hidup dan meningkatkan taraf hidupnya, Pasal 11 UU No. 39 Tahun 1999 tentang HAM : Setiap orang berhak atas pemenuhan kebutuhan dasarnya untuk tumbuh dan berkembang secara layak.

20 Hugh Collins, op.cit,: 3-4.
} 
ditentukan oleh undang-undang. Perjanjian harus dilaksanakan dengan itikad baik".

Kebebasan membuat kontrak terkait langsung dengan kebebasan yang berhubungan dengan kebebasan integrity manusia sebagaimana dapat dimaknai dari frasa "tidak seorangpun dapat dipenjara" dari Pasal 11 Kovenan Internasional Hak Sipil dan Hak Politik sebagai instrumen HAM Internasional yang lengkapnya mengatakan "tidak seorang dapat dipenjara semata-mata atas dasar ketidakmampuannya untuk memenuhi suatu kewajiban yang muncul dari perjanjian". ${ }^{21}$ Dari pasal ini dapat dikatakan, secara normatif, kebebasan membuat berkontrak adalah HAM. Dalam bahasa lain Badrulzaman menerangkan prinsip kebebasan berkontak berlaku universal karena ia berasal dari hukum alam dan perwujudan kehendak bebas sebagai pancaran HAM. ${ }^{22}$ Diskusi panjang tentang hak kebebasan berkontrak sebagai pemberian hak alamiah di Amerika ditemukan pada Spencer's Justice. Istilah kebebasan kontrak itu sendiri di Amerika pertama kali ditemukan dalam Lieber's Civil Liberty dan Self-Governmen pada tahun 1853. ${ }^{23}$

Argumentasi kuat dari sifat universalnya kebebasan berkontrak dapat dilihat dianutnya prinsip ini dalam The Unidriot Principles of International Commercial Contracts (UNIDROIT). Prinsip ini sebagai prinsip dasar dari perdagangan internasional. Kebebasan itu merupakan "cornerstone" dari tata ekonomi internasional yang terbuka, berorientasi pasar, dan kompetitif. ${ }^{24}$ Dasar pemikiran pengaturan prinsip kebebasan berkontrak dalam UNIDROIT adalah jika kebebasan berkontrak tidak diatur, maka dapat terjadi distorsi, tetapi sebaliknya apabila pengaturannya terlalu ketat, maka akan hilanglah makna dari kebebasan berkontrak itu sendiri. UNDROIT berusaha untuk mengakomodasi berbagai kepentingan yang diharapkan dapat memberi solusi persoalan perbedaan sistem hukum dan kepentingan ekonomi lainnya, sebagaimana terlihat dalam common law Inggris yang menganut paham utilitarianisme dimana inti hukum kontrak terletak pada kebebasan perdagangan dan kebebasan untuk menyelesaikan kontrak. Kebebasan kontrak utamanya kebebasan ekonomi dan untuk secara sukarela terlibat dalam transaksi ekonomi tanpa ada risiko gangguan hukum kecuali membayar pajak. Beda dengan sistem civil law yang menganut rasionalisme Prancis dan idealime Jerman yang lebih menekankan pada tugas, akal, keinginan dan semangat. ${ }^{25}$

Prinsip kebebasan berkontrak pada awalnya berlatarbelakang paham individualisme yang secara embrional lahir pada zaman Yunani, diteruskan oleh kaum Epicuristen dan berkembang pesat pada zaman renaissance melalui ajaran-ajaran Hugo de Groot (Grotius), Thomas Hobbes, John Locke, dan Rousseau yang puncak perkembangannya tercapai pada

21 Lihat juga Pasal 19 ayat (2) UUHAM : Tak seorangpun atas putusan pengadilan boleh dipidana penjara atau kurungan berdasarka atas alasan ketidakmampuan untuk memenuhi suatu kewajiban dalam perjanjian uutangpiutang.

22 Mariam Darus Badrulzaman, Kompilasi Hukum Perikatan, (Bandung: Citra Aditya Bakti, 2016), hlm. 84.

23 Roscoe Pound,. "Liberty of Contract", The Yale Law Journal, Vol. 18, No. 7 (May, 1909), pp. 454-487, http:// www.jstor.org/stable/785551 (diakses: 22 Juni 2017).

24 Taryana Soenandar, Tinjauan Atas Beberapa Aspek Hukum Dari Prinsip-prinsip UNIDROIT dan CISG, Kompilasi hukum Perikatan, (Bandung: Citra Aditya Bakti, 2016), hlm. 160.

25 Hans-W. Micklitz, loc.cit. 
periode setelah revolusi Prancis. Pada akhir abad ke XIX akibat desakan faham-faham etis dan sosialis faham individualis mulai pudar, terlebih-lebih sejak berakhirnya perang dunia kedua. Faham ini dinilai tidak mencerminkan keadilan. Masyarakat ingin pihak yang lemah lebih banyak mendapat perlindungan. Oleh harena itu, kehendak bebas tidak lagi diberi arti mutlak, akan tetapi diberi arti relatif, dikaitkan selalu dengan kepentingan umum. ${ }^{26}$ Pada abad ke XX terjadi tren perubahan dari kontrak yang bebas dibuat oleh para pihak kepada kontrak yang diatur oleh pemerintah. ${ }^{27}$ Dalam perkembangan selanjutnya, kontrol terhadap operasionalisasi asas kebebasan berkontrak dilakukan oleh legislatif melalui undang-undang banyak dilakukan di beberapa negara termasuk Indonesia; dan yang tidak kalah pentingnya kontrol juga dilakukan oleh lembaga peradilan.

Prinsip kebebasan penting dipahami karena terkait tiga hal. Pertama, kebebasan berkontrak bisa memajukan kesejahteraan umum, efisiensi ekonomi, atau beberapa tujuan lainnya. Pendekatan instrumental untuk menilai kebebasan berkontrak adalah karakteristik analisis hukum ekonomi. Kedua, kebebasan kontrak mungkin berharga dalam haknya sendiri; terlepas dari nilai instrumentalnya, kebebasan memilih mungkin merupakan hal yang penting. Mungkin orang lebih bahagia ketika mereka dapat memilih sendiri, atau mungkin memiliki lebih banyak pilihan adalah hal yang baik, terlepas dari pengaruhnya terhadap efisiensi atau kesejahteraan. Ketiga, kebebasan memilih sebagai doktrin dalam hukum kontrak. Doktrin itu mengasumsikan manusia bebas dan otonom. Mereka mampu menentukan jalan yang dianggap baik bagi dirinya, termasuk dalam membentuk institusi hidup bersama. ${ }^{28}$

Kebebasan berkontrak sebagai prinsip dasar kontrak bersumber dari kebebasan manusia, yang operasionalisasinya berimplikasi sebagai norma hukum; melalui kebebasan itu manusia bebas membuat kontrak yang berdampak menerbitkan norma hukum yang daya lakunya mengikat dan memaksa bagi lingkungan pembuatnya sendiri. Dalam berbagai literatur hukum kontrak sudah menjadi kesepahaman umum ahli hukum menyatakan kontrak sebagai hukum layaknya sebuah undang-undang. Jadi, secara normatif kontrak dianalogikan dengan undang-undang. ${ }^{29} \quad$ Namun, perlu dipahami dengan berpikir kritis spekulatif, antara kontrak dengan undang-undang terdapat perbedaan bila dilihat dari beberapa aspek yaitu (a) subjek (b) otoritas kewenangan, dan (c) lingkup daya berlakunya.

Aspek subjek pembentuk norma. Norma hukum yang dilahirkan dari suatu kontrak didasarkan pada perbuatan individu pribadi yang berlaku dalam kehidupan pergaulan hidup masyarakat yang dilakukan atas dasar individu memiliki kebebasan sebagai hak fundamental individu pribadi. Perbuatan itu ditujukan untuk membuat aturan bagi

Mariam Darus Badrulzaman, op.cit., hlm. 84-85.

27 Munir Fuady, Teori-teori Besar (Grand Theory) Dalam Hukum, (Jakarta: Kencana Prenadamedia Gooup. 2013), hlm. 234-235.

28 Yovita A. Mengesti dan Bernard L. Tanya, Moralitas Hukum, (Malang: Genta Publishing, 2014), hlm. 28.

29 Pendapat ini membedakan makna hukum dengan undang-undang baik dari segi prosedur maupun daya lakunya. 
kalangan internal mereka yang membuatnya. ${ }^{30}$ Perbuatan membuat kontrak adalah perbuatan manusiawi (actus humanus) suatu perbuatan yang mengandung nilai kemanusian, bukan perbuatan manusia (actus hominis) sebagai perbuatan pada umumnya sebagai gerak alam yang bebas nilai. Kebebasan individu untuk melakukan perbuatan membuat kontrak itu diperolehnya secara alamiah atau kodratiah karena manusia memiliki akal dan kehendak. Manusia harus memiliki kebebasan untuk melakukan tindakan. Jadi, konsep kebebasan sebagai dasar pengembangan hak, karena kebebasan berkaitan dengan martabat manusia, ia merupakan nilai dan bersifat normatif baik secara moral maupun hukum. ${ }^{31}$

Kebebasan membuat kontrak berpijak pada individu sebagai sumber dari semua kesejahteraan dan kehendak individu sebagai dasar semua kekuasaan. Kebebasan kontrak, ditambah dengan mekanisme penegakan hukum kontrak, menciptakan kondisi di mana pasar berkembang biak, membawa manfaat kedua pihak yang bertransaksi, penyaluran kekayaan yang mereka hargai lebih. ${ }^{32}$ Hubungan kontrak merupakan hubungan manusia pribadi yang dikenal hubungan sipil atau privat. Berbeda dengan norma hukum dalam bentuk undang-undang yang subjek pembuatnya adalah negara sebagai entitas tertentu dalam bentuk identitas bersama kehidupan manusia. Norma hukum undang-undang yang dibuat oleh negara didasarkan pada kebebasan yang dimiliki kekuasaan negara, dimana kebebasan negara itu diperoleh berasal dari kontrak sosial (perjanjian sosial).

Aspek otoritas kewenangan pembuat norma. Dalam lingkup hak sipil yang tidak mengandung kekuasaan politik. Norma hukum yang dibangun dan dibentuk berdasarkan kontrak ditegakkan atas inisiatif murni dari pembuatnya. Negara baru dapat hadir apabila para pihak menghendakinya. Posisi negara di sini sebagai alat bantu bagi para pihak jika norma hukum tersebut tidak berjalan sebagaimana mestinya. Individu boleh membuat peraturannya sendiri yang menurutnya baik, akan tetapi secara subsidair, pembentuk undang-undang menunjukkan apa yang akan berlaku bila peraturan pembentukan sendiri itu tidak ada. ${ }^{33}$ Pada sisi lain, Kelsen menerangkan penciptaan norma hukum oleh individu dalam kontrak berkaitan dengan penentuan nasib sendiri yang sah, yakni otonomi, hanya ada dalam pengertian yang sangat terbatas; karena hak tak seorangpun dapat menciptakan hak untuk dirinya sendiri, sebab hak seseorang mensyaratkan adanya kewajiban dari orang lain. ${ }^{34}$ Norma hukum dengan karakter undangundang dibentuk oleh negara sebagai entitas

30 Lihat Glann, op.cit., hlm. 13 : Idealnya suatu perbuatan baru dikatakan perbuatan kontrak bila berupa penyampaian niat yang dilakukan dengan sengaja dan efektif untuk membawa perubahan dalam situasi normatif orang tersebut yaitu berkaitan dengan hak dan kewajiban. Bandingkan dengan beberapa penulis mengkritisi ungkapan "perbuatan" dari definisi kontrak yang dinilai mengandung kelemahan dan terlalu luas, sebagimana diungkapkan oleh KMRT Tirtodiningrat, Setiawan, Suryodiningrat, Purwahid Patrik, Athur S.Hartkamp dan Marriane M.M.Tillema yang menurut mereka seharusnya ungkapan "perbuatan" disebut dengan "perbuatan hukum".

31 Zulfirman, op.cit., hlm. 134

32 Adam J. Hirsch, op.cit., : 2187.

33 Ibid.

34 Hans Kelsen, Teori Hukum Murni, Dasar-Dasar Ilmu Hukum Normatif, terjemahan Raisul Muttaqien, (Bandung: Nusamedia dan Nuansa, 2007), hlm. 192. 
politik yang kewenangannya berasal dari kontrak sosial sebagai perwujudan hak politik individu melalui kontrak sosial. Norma hukum dalam karaker undang-undang ditegakkan atas inisiatif murni oleh negara demi kepentingan, ketertiban dan ketenteraman umum.

Aspek daya laku norma. Norma hukum yang lahir dari kontrak daya lakunya pada lingkungan internal yang mengikat dan memaksa bagi pembuatnya sendiri. Bentuk norma hukumnya konkrit individual, sedangkan daya laku norma hukum undang-undang berlaku umum, mengikat dan memaksa bagi semua orang termasuk bagi pembuatnya. Bentuk norma hukumnya bersifat abstrak dan umum.

J. Cartwright menyebutkan ada dua visi dari kebebasan berkontrak. Pertama, visi pasar di mana kebebasan berkontrak sebagai institusi hukum dan komersial untuk mendukung mendukung pasar bebas dan terbuka dan, lebih khusus lagi, peran hukum kontrak terutama (atau setidaknya umumnya) untuk mendukung dan memfasilitasi transaksi pasar. Kedua, visi sukarela dari kebebasan berkontrak, hal ini dapat dilihat sebagai satu prinsip moral. Prinsip ini sebagai dasar pembenaran melakukan pilihan dari pihak individu untuk memasuk pada suatu kontrak. Visi kebebasan berkontrak ini sering diungkapkan dalam hukum Eropa Kontinental dengan ungkapan "otonomi kontraktual" yang akarnya berasal dari filsafat Rosseau dan Kant. ${ }^{35}$

Mariana Semini menerangkan otonomi kehendak bebas dalam kontrak mengandung tiga aspek penting. ${ }^{36}$ Pertama, aspek filosofis didasarkan pada pandangan Rosseau, bahwa manusia secara alami bebas, karena itu harus bebas membangun setiap hubungan hukum. Para pendukung pandangan ini menerima apa yang disebut kontrak sosial. Menurut hemat penulis esensi teori kehendak membuat kontrak akarnya adalah kebebasan dan ia menjadi pusat kajian utama filsafat, ${ }^{37}$ hal itu disebabkan karena ia merupakan fondasi nilai-nilai kemanusia.

Kedua, aspek moral dimana setiap kontrak harus memenuhi keadilan. Di mana ada kontrak, di sana ada keadilan. Kontrak harus menjadi kepentingan kedua belah pihak, oleh karenanya kedua pihak harus membangun semacam hubungan satu sama lain untuk mencapai sesuatu yang akan bermanfaat bagi mereka. Para pihak yang membangun kontrak harus berlaku jujur satu sama lainnya, seimbang dan tidak memihak berdasarkan akal sehat.

Ketiga, aspek ekonomi. Kebebasan kehendak harus sesuai dengan pencapaian kepentingan ekonomi, karena materi ini atau tidak bahan dari pihak kontrak. Dengan kata lain, kepentingan ini harus disertai dengan kenaikan kuantitas dari produksi, kenaikan harga, pengurangan biaya, menciptakan kompetisi dan lain lain.

Dari apa yang diterangkan di atas terlihat kebebasan berkontrak sesungguhnya berkaitan dengan keberadaan manusia yang memiliki hak fundamental yaitu kebebasan, hak hidup, dan milik. Itu semua menyangkut harkat dan martbat manusia yang berhubungan dengan kualitas hidup. Apa yang disebutkan terakhir ini pada intinya adalah tentang kesejahteraan. Jadi, kontrak adalah sarana hukum yng digunakan untuk mengejar kesejahteraan, baik itu

35 Tedoradze Irakli, "The Principle of Freedom of Contract, Pre-Contractual Obligations Legal Review English, EU and US Law", European Scientific Journal, Vol. 13, No. 4, ( February 2017): 62 -63.

36 Irena Lavdari, op.it., : 430-431.

37 Lihat T.S.N.Sasrty, Intruduction to Human Rights and Duties, (Pune: University of Pune Press,Ganeshkhinda, 2011), hlm. 17. 
kesejahteraan pribadi maupun kesejahteraan hidup bersama (sosial).

\section{Kebijakan negara terhadap kontrak sebagai sarana mewujudkan kesejahteraan sosial}

Pada kesempatan di atas telah diulas kebebasan berkontrak merupakan prinsip yang berlaku bagi hukum kontrak yang intinya menyangkut dua hal. Pertama, kontrak sebagai perwujudan kebebasan manusia. Kedua, kontrak sebagai sarana mencapai kesejahteraan ekonomi munusia baik secara pribadi maupun kolektif. Apa yang disebutkan terakhir berhubungan dengan kebutuhan (ekonomi) manusia dan yang disebutkan lebih awal tentang kebebasan integrity manusia. Dari dua hal itu, tidak dapat dipungkiri pembahasan ekonomi tidak terlepas dari kebebasan. D.F. Scheltens berpendapat kebebasan adalah satu-satunya yang dibicarakan dalam hukum dan politik. $^{38}$ Oleh karenanya, pengaturan keduanya dalam bentuk undang-undang tidak terlepas dari pandangan hidup (filsafat hidup) suatu bangsa (negara) tidak terkecuali bagi bangsa (negara) Indonesia.

Bagi bangsa Indonesia arti kebebasan dan ekonomi (kesejahteraan) menjadi dasar perjuangan kemerdekaan Indonesia. Fakta sejarah Indonesia memberikan bukti, Penjajah bangsa Indonesia telah mengeksplotasi manusia dan sumber daya alam (ekonomi) Indonesia sampai pada titik nadir terendah yang memperkosa sisi-sisi kemanusiaan manusia. Fakta itu jelas tergambar dalam Pembukaan
UUD 1945, dan dari sana pulalah digali nilainilai ideologi negara Indonesia yang wujud formalnya termuat dalam Pancasila sebagai landasan ideologi negara Indonesia.

Bagi bangsa Indonesia Pancasila merupakan sumber segala sumber hukum. Hukum yang dibangun harus berdasarkan Pancasila. ${ }^{39}$ Pancasila itu sendiri pada hakekatnya berbicara tentang manusia. W.Poesoprodjo mengatakan pada manusia dinisbahkan tiga hal, yaitu sebagai makhluk religius, makhluk sosial dan makhluk posesif. ${ }^{40}$ Dalam Pancasila, manusia sebagai makhluk religius dapat dilihat dari sila Ketuhanan Yang Maha Esa. Manusia sebagai makluk sosial dapat dilihat dari sila kemanusiaan yang adil dan beradab, sila Persatuan Indonesia, dan sila Kerakyatan yang dipimpin oleh hikmah kebijaksanaan dalam permusyawaratan perwakilan. Manusia sebagai makluk posesif tercermin dalam sila Keadilan Sosial bagi seluruh Rakyat Indonesia. Penulis berkeyakinan inti paling mendasar dari Pancasila adalah tekad untuk menjaga, merawat, melindungi dan memperjuangkan kehidupan. Dari situ makna hukum dalam pandangan Pancasila adalah suatu cita-cita hidup bersama bagaimana memperlakukan manusia sebagai manusia, dalam kapasitasnya sebagai makhluk religius, makhluk sosial maupun makhluk posesif. Hal ini mempunyai pengaruh terhadap visi hukum Indonesia.

Secara umum dikenal dua visi hukum, yaitu visi idealitas spritualitas dan visi materalistis sosiologis. Visi yang disebutkan pertama berpandangan hukum itu sebagai suatu

\footnotetext{
38 Zulfirman, op.cit., hlm. 99.

39 Lihat Pasal 2 Undang-undang Nomor 12 Tahun 2011 tentang Pembentukan Peraturan Perundang-undangan : Pancasila merupakan sumber segala sumber hukum negara.

$40 \quad$ Zulfirman, op.cit., 98.
} 
perwujudan gagasan absolut, sedangkan visi hukum yang disebutkan terakhir hukum dipandang sebagai produk kenyataan masyarakat atau realitas sosial. Visi hukum yang disebutkan terakhir ini mutlak dipandang mata-mata produk ratio manusia. ${ }^{41}$ Dua visi hukum itu mempunyai pengaruh terhadap pembentukan hukum. Para penganut visi idealitas spiritualitas berpatokan pada wahyu atau keyakinan spiritual, sedangkan penganut visi materialis sosiologis berpatokan para ratio atau akal dalam mencermati fenomena kehidupan sosial manusia.

Bentuk visi hukum Indonesia berdasarkan Pancasila adalah visi idealitas spritualitas. Hal ini secara jelas dapat dilihat dari Pasal 29 ayat (1) UUD RI 1945 yang mengamanahkan "Negara Indonesia berdasarkan ke-Tuhanan Yang Maha Esa" yang dijabarkan lebih lanjut dalam kekuasaan kehakiman. ${ }^{42}$ Dalam Pasal 2 ayat (1) Undang-undang Nomor 48 Tahun 2009 tentang Kekuasaan Kehakiman mengatakan : Peradilan dilakukan "DEMI KEADILAN BERDASARKAN KETUHANAN YANG MAHA ESA". Ketuhanan Yang Maha Esa pada intinya ranah agama dan bentuk pemujaan pada Tuhan. Tanpa pemujaan terhadap Tuhan kehidupan manusia itu menjadi menyusut dan menurunkan derajat manusia pada tingkat yang paling bawah yang tidak memiliki makna kehidupan sama sekali. Jadi, agama membawa peranan penting karena melaluinya menambahkan sesuatu yang penting bagi substansi manusia dan jika ia ditolak atau diabaikan tampaknya akan menghasilkan akibat melumpuhkan pada kehidupan manusia. ${ }^{43}$

Visi hukum idealitas spritualitas berdasarkan Pancasila menjadi titik tolak untuk membahas semua hukum di Indonesia termasuk hukum kontrak khususnya lagi untuk menafsir asas kebebasan berkontrak yang berlaku dalam hukum kontrak Indonesia dalam hubungannya mewujudkan kesejahteraan sosial yang menjadi tugas pemerintah Negara Indonesia.

Dalam tulisan ini dipilih dua undangundang untuk dicermati terkait operasionalisasi kebebasan berkontrak dalam kaitannya dengan kesejahteraan sosial yaitu UU Anti Monopoli dan UUPK. Dalam UU Anti Monopoli kontrol daya berlakunya asas kebebasan berkontrak dapat dilihat ketentuan norma hukum larangan membuat kontrak sebagai termuat dalam Pasal 4 tentang oligapoli, Pasal 5,6, 7 dan 8 tentang penetapan harga, Pasal 9 tentang pembagian wilyah pemasaran, Pasal 10 tentang pembaikotan, Pasal 11 tentang kartel, Pasal 12 tentang trust, Pasal 13 tentang oligopsoni, Pasal 14 tentang integrasi vertikal, Pasal 15 tentang perjanjian tertutup, dan Pasal 16 tentang perjanjian luar negeri.

Latar belakang dibentuknya norma hukum larangan perjanjian dalam UU Anti Monopoli dijelaskan dalam penjelasan umum di mana sebelumnya kebijakan pemerintah dinilai kurang tepat sehingga pasar menjadi terdistorsi. Di sisi lain, perkembangan usaha swasta dalam kenyataannya sebagian besar merupakan

41 John Gilissen dan Frits Gorle, Sejarah Hukum Suatu Pengantar, terjemahan Freddy Tengker, Bandung: Refika Aditama, 2005, hlm. 13-14.

42 Lihat juga pada irah-irah setiap undang-undang yang menyebutkan : DENGAN RAHMAT TUHAN YANG MAHA ESA.

43 Henryk Skolimowski, Filsafat Lingkungan, terjemahan Saut Pasaribu, (Yogyakarta: Bentang Budaya, 2004), hlm. 146. 
perwujudan dari kondisi persaingan usaha yang tidak sehat.

Fenomena di atas telah berkembang dan didukung oleh adanya hubungan yang terkait antara pengambil keputusan dengan para pelaku usaha, baik secara langsung maupun tidak langsung, sehingga lebih memperburuk keadaan. Penyelenggaraan ekonomi nasional kurang mengacu kepada amanat Pasal 33 Undang-Undang Dasar 1945, serta cenderung menunjukkan corak yang sangat monopolistik. Parapengusahayang dekat dengan elitkekuasaan mendapatkan kemudahan-kemudahan yang berlebihan sehingga berdampak kepada kesenjangan sosial. Munculnya konglomerasi dan sekelompok kecil pengusaha kuat yang tidak didukung oleh semangat kewirausahaan sejati merupakan salah satu faktor yang mengakibatkan ketahanan ekonomi menjadi sangat rapuh dan tidak mampu bersaing. Dari penjelasan umum ini dapatlah dilihat dasar pemikiran pembentukan UU Anti Monopoli setidaknya memuat tiga hal, yaitu :

a. Pembangunan bidang ekonomi harus diarahkan kepada terwujudnya kesejahteraan rakyat;

b. Demokrasi dalam bidang ekonomi menghendaki adanya kesempatan yang sama bagi setiap warga negara untuk berpartisipasi di dalam proses produksi dan pemasaran barang dan/atau jasa, dalam iklim usaha yang sehat, efektif, dan efisien, sehingga dapat mendorong pertumbuhan ekonomi dan bekerjanya ekonomi pasar yang wajar;

c. Setiap orang yang berusaha di Indonesia harus berada dalam situasi persaingan yang sehat dan wajar, sehingga tidak menimbulkan adanya pemusatan kekuatan ekonomi pada pelaku usaha tertentu.

Terkait dengan itu, dapat dipahami landasan berpikir legislatif membentuk norma hukum sehubungan dengan operasionalisasi kebebasan berkontrak pada umumnya dan di dunia bisnis pada khususnya, memandang kontrak berhubungan dengan ekonomi atau kesejahteraan masyarakat. Rasio dari ketentuan larangan membuat kontrak dalam undangundang anti monopoli adalah mewujudkan keadilan distributif ${ }^{44}$ yang dipunyai oleh negara dengan menerapkan prinsip proporsionalitas atas pemanfaatan sumber daya ekonomi dan sumber daya alam. Perlunya pengaturan terhadap pemanfaatan sumber daya alam dan ekonomi oleh negara karena dua hal tersebut sebagai penyokong kehidupan manusia. ${ }^{45}$

44 Abdul Munif, Perikatan Bersyarat Batal, (Yogyakata: FH UII Press, 2016), hlm. 24: Keadilan distributif mengacu pada pembagian barang dan jasa kepada setiap orang sesuai dengan kedudukannya dalam masyarakat, dan perlakukan yang sama terhadap kesederajaan di hadapan hukum (equality before the law). Lihat juga Mokhamad Khoitul Huda, Prinsip Iktikad Baik Dalam Perjanjian Asuransi Jiwa, (Yogyakarta: FH UII Press, 2016), hlm. 34 : Keadilan distributif merupakan urusan pembentuk undang-undang. Lihat lagi Agus Santoso, Hukum, Moral \& Keadilan Sebuah Kajian Filsafat Hukum, (Jakarta: Kencana Prenada Media Group, 2012), hlm. 92 : Keadilan distributif yaitu suatu hubungan keadilan antara negara terhadap warganya, dalam arti pihak negaralah wajib memenuhi keadilan dalam bentuk keadilan membagi dalam bentuk kesejahteraan, bantuan, subsidi serta kesempatan dalam hidup bersama yang didasarkan atas hak dan kewajiban.

45 Lihat Forum Keadilan, "Laut Natuna Utara Bikin Beijing Gerah", Majalah Forum Keadilan, No. 07, 06 Agustus 2017, hlm. 80 : Yurisprudensi hukum internasional dalam kasus arbitrase Filipina dan Tiongkok memutuskan pulau yang kecil atau karang yang kecil yang ada di tengah laut yang tidak bisa menyokong kehidupan manusia tidak memiliki hak ZEE 200 mil laut dan landas kontinen. 
Larangan perjanjian dalam undang-undang anti monopoli ditujukan pada pengaturan hak fundamental individu tentang kepemilikan atau kekayaan yang dipandang dari aspek ekonomi. Pemanfaatan sumber daya ekonomi dan sumber daya alam dilihat dari sisi utility public yang ditujukan untuk kesejahteraan sosial bukan pengaturan tentang kebebasan integrity individu. Dalam sudut pandang ini maka kontrak dipandang dari sisi kemasyarakatannya dimana semua hak milik mempunyai fungsi sosial. ${ }^{46}$ Apa yang disebutkan terakhir ini tergambar bahwa negara Indonesia adalah suatu negara kesejaheraan (welfare State) sesuai dengan apa yang ditentukan di dalam Pembukaan UUD 1945 yang mengharuskan terwujudnya demokrasi ekonomi di Indonesia.

Fungsi sosial dalam pandangan Indonesia menjadi pusat pengaturan hak termasuk pengaplikasian kebebasan dalam bidang ekonomi. Oleh karena itu, legislatif memandang kontrak saat ini tidak menafsirkan secara subjektif semata-mata dalam kegiatan ekonomi atau kesejahteraan sosial, tetapi kontrak telah ditafsirkan secara objektif yakni sisi kemasyarakatan dari suatu kontrak. ${ }^{47}$ Perlu ditekankan pula, penafsiran objektif ini dipergunakan pemanfaatan sumber daya ekonomi dan sumber daya alam sebagai utility public yang bersifat umum dan bebas sebagai karunia Tuhan. Dalam hal ini, legislatif memandang semua semua pihak mempunyai kesempatan yang sama untuk mendayagunakan sumber ekonomi dan sumber daya alam Indonesia berdasarkan prinsip demokrasi ekonomi dengan tujuan bagaimana terwujudnya kualitas hidup yang pantas.

Sekarang tibalah saatnya membahas operasionalisasi prinsip kebebasan berkontrak dalam UUPK. Norma hukum yang mengatur terkait dengan kontrak secara ekspilit ditentukan pada Pasal 1 butir 10 UUPK yang mengatakan : Klausula Baku adalah setiap aturan atau ketentuan dan syarat-syarat yang telah dipersiapkan dan ditetapkan terlebih dahulu secara sepihak oleh pelaku usaha yang dituangkan dalam suatu dokumen dan/atau perjanjian yang mengikat dan wajib dipenuhi oleh konsumen. Terkait klausula baku tersebut dijabarlah lebih jauh dalam Pasal 18 ayat (1) UUPK yang mengatakan: "Pelaku usaha dalam menawarkanbarangdan/ataujasayangditujukan untuk diperdagangkan dilarang membuat atau mencantumkan klausula baku pada setiap dokumen dan/atau perjanjian apabila (a) menyatakan pengalihan tanggung jawab pelaku usaha (b) menyatakan bahwa pelaku usaha berhak menolak penyerahan kembali barang yang dibeli konsumen (c) menyatakan bahwa pelaku usaha berhak menolak penyerahan kembali uang yang dibayarkan atas barang dan/atau jasa yang dibeli oleh konsumen (d) menyatakan pemberian kuasa dari konsumen kepada pelaku usaha baik secara langsung maupun tidak langsung untuk melakukan segala tindakan sepihak yang berkaitan dengan barang yang dibeli oleh konsumen secara angsuran (e) mengatur perihal pembuktian atas hilangnya kegunaan barang atau pemanfaatan jasa yang dibeli oleh konsumen (f) memberi

46 Lihat Pasal 36 ayat (3) Undang-undang Nomor 39 Tahun 1999 tentang Hak Asasi Manusia: Hak Milik mempunyai fungsi sosial. Ketentuan ini dimuat dalam Bagian Ketujuh tentang Hak Atas Kesejahteraan.

47 Bandingkan dengan prinsip kebebasan berkontrak dalam konotasi laissez faire aliran filsafat politik politik dan ekonomi liberal yang dipelopori Adam Smith yang menafsirkan kebebasan berkontrak dari sisi subjektif. 
hak kepada pelaku usaha untuk mengurangi manfaat jasa atau mengurangi harta kekayaan konsumen yang menjadi obyek jual beli jasa (g) menyatakan tunduknya konsumen kepada peraturan yang berupa aturan baru, tambahan, lanjutan dan/atau pengubahan lanjutan yang dibuat sepihak oleh pelaku usaha dalam masa konsumen memanfaatkan jasa yang dibelinya (h) menyatakan bahwa konsumen memberi kuasa kepada pelaku usaha untuk pembebanan hak tanggungan, hak gadai, atau hak jaminan terhadap barang yang dibeli oleh konsumen secara angsuran".

Lebih lanjut Pasal 18 ayat (2) UUPK dikatakan: "Pelaku usaha dilarang mencantumkan klausula baku yang letak atau bentuknya sulit terlihat atau tidak dapat dibaca secara jelas, atau yang pengungkapannya sulit dimengerti". Dalam Pasal 18 ayat (3) UUPK dinyatakan : "Setiap klausula baku yang telah ditetapkan oleh pelaku usaha pada dokumen atau perjanjian yang memenuhi ketentuan sebagaimana dimaksud pada ayat (1) dan ayat (2) dinyatakan batal demi hukum".

Dalam penjelasan umum UUPK pada alinea ketiga dijelaskan latar belakang diterbitknya UUPK adalah didasarkan fakta kedudukkan pelaku usaha dan konsumen menjadi tidak seimbang dan konsumen berada pada posisi lemah. Konsumen menjadi objek aktivitas bisnis untuk meraup keuntungan yang sebesarbesarnya oleh pelaku usaha melalui kiat promosi, cara penjualan, serta penerapan perjanjian standar yang merugikan konsumen. Bertitik tolak dari penjelasan umum ini dan dihubungkan dengan norma hukum yang termuat pada Pasal 18 ayat (1), ayat 2 ), ayat (3) UUPK dapat dipetik maknanya tujuan umum dari UUPK dimana legislatif berupaya melindungi kebebasan integrity manusia dalam membuat kontrak. Hak kebebasan manusia untuk menyampaikan kehendak bebas tidak dapat diperlakukan sebagai objek ekonomi. Hukum sebagai instrumen yang mengatur manusia, dituntut memiliki idealisme tentang keluruhan nilai dan martabat manusia. ${ }^{48} \mathrm{Hal}$ ini jelas terlihat dari ketentuan yang bersifat memaksa yang harus dipenuhi oleh pelaku usaha dalam membuat dokumen kontrak baku yang pada prinsipnya tidak boleh mencantumkan klausula pengalihan tanggungjawab dan penyampaian informasi secara lengkap dan benar tentang produk barang dan/atau jasa yang akan didistibusikan.

Penulis menilai alasan dilakukannya kontrol terhadap daya laku kebebasan berkontrak atas dasar tidak adanya posisi tawar yang seimbang antara para pihak pembuat kontrak telah menimbulkan masalah yang serius terhadap kehidupan pribadi yang menyerang kebebasan seseorang. Untuk itu prinsip itu tidak lagi ditafsirkan secara subjektif dalam melindungi hak sipil seseorang tetapi berubah menjadikan kontrak ditafsirkan secara objektif demi keberadaan dan penghormatan atas kebebasan sipil (HAM). Dalam perkembangannya saat ini hak konsumen merupakan generasi keempat HAM dalam perkembangan umat manusia di masa-masa yang akan datang. ${ }^{49}$ Intinya secara ideologis kebijakan hukum di Indonesia termasuk perlindungan konsumen, bangsa Indonesia menganut prismatika antara

48 Yovita A. Mengesti dan Bernad L. Tanya, op.cit., hlm. 18.

49 Firman Tumantara Endipradja, Hukum Konsumen Perlindungan Konsumen, ( Malang: Setara Press, 2016), hlm. 100. 
indivudialisme dan kolektivime dengan titik berat pada kesejahteraan umum dan keadilan sosial. ${ }^{50}$

Hemat penulis kebijakan hukum yang dianut oleh bangsa Indonesia adalah melapiskan nilai individualisme dan nilai kolektivisme atau dengan kata lain melapiskan nilai kebebasan dengan nilai persamaan. Terkait dengan perlindungan konsumen, intinya adalah upaya menciptakan kesejahteraan sosial dan sekaligus melakukan perlindungan sosial dengan tetap mempertahankan keberadan individu sebagai roda aktivitas kehidupan sosial. Bagaimanapun tidak dapat dihindari tanpa manusia bersifat makhluk sosial maka tidaklah dimungkinkan hidup berkelanjutan.

Dari penjelasan umum itu dapat dilihat legislatif mengkontrol asas kebebasan berkontrak, khususnya pencantuman klausula standar, kesemuanya itu untuk melindungi kebebasan dasar seseorang untuk masuk kedalam suatu kontrak dan mecegah risiko yang menyerang langsung dengan kebebasan, keselamatan diri dari pelaku kontrak. Apa yang disebutkan terakhir ini dapat dipahami melalui ketentuan Pasal 19 UUPK adanya kewajiban pelaku usaha untuk memberi ganti rugi atas kerusakan, pencemaran, dan/atau kerugian konsumen akibat mengkonsumsi barang dan/ atau jasa yang dihasilkan atau diperdagangkan. Bahkan lebih jauh lagi ada sanksi pidana bagi pelaku usaha bila terdapat unsur kesalahan di dalamnya.

Dari dua undang-undang yang dikaji dalam tulisan ini dapat dilihat, kontrol terhadap daya laku prinsip kebebasan berkontrak dalam UU Anti Monopoli dan UUPK pada prinsipnya adalah untuk menciptakan kesejahteraan sosial dan memandang kontrak dari sisi kemasyarakatan dan asas kebebasan berkontrak ditafsirkan secara objektif oleh legislatif atau negara. Pada sisi lain dapatlah dikatakan kedua undangundang tersebut adalah bentuk perlindungan, penghormatan, dan pemenuhan HAM individu oleh negara. Hassmann menerangkan individu manusia mempunyai hak-hak asasi mereka, sementara negara dan entitas lainnya wajib untuk menghormati, melindungi, dan memenuhi hak mereka. Menghormati HAM berarti tidak melanggarnya, melindungi HAM berarti memastikan bahwa HAM tidak dilanggar orang lain, memenuhi HAM berarti menerapkan langkah-langkah positif untuk memastikan bahwa individu menikmati hak-haknya. ${ }^{51}$

Pengaruh perlindungan dan penghormatan terhadap hak sipil sebagai HAM telah memberi warna tersendiri terhadap prinsip kebebasan berkontrak. Kontrol pemerintah atau negara terhadap kebebasan berkontrak, khususnya dalam UU Anti Monopoli dan UUPK, sebagai bentuk kewajiban pemerintah atau negara terhadap HAM. Henry Shue menerangkan kewajiban negara terhadap HAM yaitu kewajiban kesabaran (forbearance duties), kewajiban perlindungan (protetion duties) dan kewajiban perbantuan (assistance duties). Kewajiban jenis pertama dan kedua menitik beratkan upaya pencegahan dari pelanggaran HAM. Kewajiban ini termasuk memenuhi HAM yang positif dan negatif. Adapun jenis ketiga

Ibid., hlm. 101.

51 Rhoda E. Howard-Hassmann, “Human Security : Undermining Human Roghts?" Human Rights Quarterly, The Johns Hopkins University Press, Vol. 34 N0. 1 (February 2012), hlm. 93. 
lebih dominan HAM positif Negara. ${ }^{52}$ Kewajiban negara ini pada intinya berujung pada bagaimana kehidupan dapat dipertahankan, dilindungi dan dijaga demi kehidupan manusia itu baik dalam posisinya sebagai makhluk sosial maupun makhluk individu. Tegasnya pengaturan pembatasan kebebasan berkontrak dalam UU Anti Monopoli dan UUPK adalah negara berupa untuk menciptakan model solidaritas legal sebagai ciri dari negara kesejahteraan. ${ }^{53}$

Dari pembatasan daya berlakunya kebebasan berkontrak dalam UU Anti Monopoli dan UUPK mendorong perdagangan dan investasi yang efisien. Pertama, seseorang dapat berargumen bahwa perusahaan terkadang tidak melakukannya memaksimalkan keuntungan dan, karena kesalahan kognitif sistematis yang dibuat oleh orang-orang yang menjalankannya, tidak mampu melakukannya sebaiknya mereka coba. Dengan demikian, sebuah undang-undang yang mengandaikan akan memaksimalkan keuntungan menjadi salah arah. Kedua, perusahaan yang memaksimalkan keuntungan kadang melakukan hal buruk - misalnya mencemari lingkungan, hukum harus berusaha menghalanginya. Ketiga, negara harus mempromosikan keadilan dalam kontrak selain efisiensi. Keempat, negara harus mengejar tujuan distribusi meskipun terkadang bertentangan dengan efisiensi. ${ }^{54}$

Dari analisis di atas dapatlah disarikan, terbitkannya UU Anti Monopoli dan UUPK ditujukan untuk melindungi, memenuhi, dan menghormati kebebasan berkontrak sebagai HAM dan sebagai usaha untuk mengatur perilaku bisnis untuk mewujudkan kesejahteran sosial. Tujuannya menjaga kehidupan berjalan sebagaimana mestinya. Kontrol terhadap daya laku kebebasan berkontrak adalah memberi kesempatan pada semua pihak untuk dapat mengembangkan dirinya secara patut dan pantas dalam kehidupan masyarakat dan menciptakan keseimbangan kepentingan antara pelaku usaha dengan masyarakat sehingga terwujudlah keenakan hidup yang pantas. Pada titik itulah kesejahteran sosial menampakan dirinya bahwa manusia sebagai makhluk individu sekaligus makhluk sosial. Di situ kehidupan semua manusia dapat berlanjut.

\section{Penutup}

Dari analisis terhadap kebijakan hukum terhadap daya laku kebebasan berkontrak sebagai prinsip utama hukum kontrak yang berlaku universal, termasuk hukum kontrak di Indonesia, dapatlah diambil kesimpulan sebagai berikut: Pertama, kontrak adalah implementasi hak hidup, kebebasan dan milik dalam interakasi antar sesama manusia yang diimplementasikan kedalam hukum guna menghormati, melindungi, dan memenuhinya sebagai hak asasi manusia. Kedua, prinsip kebebasan berkontrak berkaitan dengan kebebasan integrity manusia yang memiliki hak fundamental menyangkut harkat

52 El Majda Muhtaj, Dimensi-dimensi HAM Mengurai Hak Ekonomi, Sosial, dan Budaya, (Jakarta : Raja Grafindo Persada, 2009), hlm. 31.

53 Lihat Dorien Pessers, "The Normative Foundation of Legal Orders: A Balance Between Reciprocity and Mutuality", Netherlands Journal of Legal Philosophy 2014 (43) 2 : 154 : Negara-negara kesejahteraan Eropa Barat adalah contoh yang banyak diperdebatkan tentang model solidaritas legal. Warga negara bersedia memberikan - dengan membayar pajak dan biaya sosial - kepada sesama warga negara, yakin bahwa mereka akan menerima bagian mereka ketika waktu kebutuhan mereka telah tiba.

54 Alan Schwartz dan Robert E. Scott, "Contract Theory and The Limits of Contract Law", Yale Law School Legal Scholarship Repository, (2003) : 5, http://digitalcommons. law.yale.edu/ lepp_papers (diakses 27 Juli 2017). 
dan martbat manusia yang berhubungan dengan kualitas hidup atau kesejahteraan pribadi dan kesejahteraan hidup bersama manusia. Ketiga, daya laku prinsip kebebasan berkontrak dibatasi dalam kegiatan dunia usaha di Indonesia ditujukan untuk menyeimbangkan kesejahteraan individu dan kesejahteraan masyarakat. Pembatasan daya laku kebebasan berkontrak dalam undang-undang sebagai usaha negara menciptakan solidaritas legal yang dibuat oleh negara Indonesia dengan menafsirkannya secara objektif terhadap prinsip kebebasan berkontrak dari sisi kemasyarakatan demi terwujudnya kesejahteraan masyarakat (sosial) dengan cara negara menerapkan keadilan distributif terkait pemanfaatan sumber daya alam dan sumber daya ekonomi; berbeda penafsiran daya laku kebebasan berkontrak menurut perspektif paham individualisme kontrak ditafsirkan dari sisi subjektif yaitu untuk mengejar kesejahteraan individu.

Oleh sebab itu maka disarankan agar dilakukan sosialisasi tentang penafsiran daya laku kontrak kepada seluruh praktisi hukum dan praktisi ekonomi berdasarkan idiologi bangsa Indonesia agar kontrak digunakan sebagai sarana mengimplementasikan HAM untuk mewujudkan kesejahteraan sosial dan individu di Indonesia sesuai dengan fungsi dan tugas negara Indonesia sebagai negara kesejahteraan.

\section{Daftar Pustaka}

\section{Buku}

Badrulzaman, Mariam Darus, Kompilasi Hukum Perikatan, (Bandung: Citra Aditya Bakti, 2016)

Billah, Mohd Ma'sum, Islamic E-Comerce Terapan, Tinjauan Hukum dan Praktek, terjemahan Ahmad Dumyathi Bashori (Petaling Jaya, Selangor, Malaysia: Sweet \& Maxwell Asia, 2010)

Dirdjosisworo, Soejono, Misteri dibalik Kontrak Bermasalah (Bandung: Mandar Maju, 2002)
Endipradja, Firman Tumantara, Hukum Konsumen Perlindungan Konsumen (Malang: Setara Press, 2016)

Fuady, Munir, Teori-teori Besar (Grand Theory) Dalam Hukum (Jakarta: Kencana Prenadamedia Gooup. 2013)

Gilissen, John dan Frits Gorle, Sejarah Hukum Suatu Pengantar, terjemahan Freddy Tengker (Bandung: Refika Aditama, 2005)

Glenn, H. Patrick, Legal Traditions of The The World Sustsainable Diversity in Law (Oxford : Oxford University Press, 2000)

Huda, Mokhamad Khoitul, Prinsip Iktikad Baik Dalam Perjanjian Asuransi Jiwa (Yogyakarta: FH UII Press, 2016)

Kasim, Ifdal dan Johannes de Masenus Arus (ed), Hak Ekonomi, Sosial, Budaya Essai-essai pilihan, terjemahan elsam (Jakarta: Elsam, 2012)

Kelsen, Hans, Teori Hukum Murni, Dasar-Dasar Ilmu Hukum Normatif, terjemahan Raisul Muttaqien (Bandung: Nusamedia dan Nuansa, 2007)

Khairandy, Ridwan, Iktikad baik dalam Kebebasan Berkontrak, (Jakarta: Universitas Indonesia, Pascasarjana, 2003)

Leback, Karen Six Theorities of Justice, terjemahan Yudi Santoso (Bandung: Nusa Media, 2012)

Mengesti, Yovita A. dan Bernard L. Tanya, Moralitas Hukum (Malang: Genta Publishing, 2014)

Moch, Insaeni, Perkembangan Hukum Perdata di Indonesia (Yogyakarta : Laksbang Grafika, 2013)

Muhtaj, El Majda, Dimensi-dimensi HAM Mengurai Hak Ekonomi, Sosial, dan Budaya (Jakarta : Raja Grafindo Persada, 2009)

Munif, Abdul, Perikatan Bersyarat Batal (Yogyakata: FH UII Press, 2016)

Santoso, Agus, Hukum, Moral \& Keadilan Sebuah Kajian Filsafat Hukum (Jakarta: Kencana Prenada Media Group, 2012)

Sasrty, T.S.N., Intruduction to Human Rights and Duties (Pune: University of Pune Press, Ganeshkhinda, 2011)

Skolimowski, Henryk, Filsafat Lingkungan, terjemahan Saut Pasaribu (Yogyakarta: Bentang Budaya, 2004)

Soenandar, Taryana, Tinjauan Atas Beberapa Aspek Hukum Dari Prinsip-prinsip UNIDROIT dan CISG, Kompilasi hukum Perikatan (Bandung: Citra Aditya Bakti, 2016)

Zulfirman, Hak Dasar Manusia Dalam Kontrak dan Perlindungannya di Indonesia (Malang: Intelegensia Media, 2017) 


\section{Makalah/Artikel/Prosiding/Hasil Penelitian}

Collin, Hugh, "The Impact of Human Rights Law on Contract Law in Europe, University of Cambridge Faculty of Law Legal Studies, Paper, No. 13, (2011)

Forum Keadilan, "Laut Natuna Utara Bikin Beijing Gerah", Majalah Forum Keadilan, No. 07, 06 Agustus 2017

Hirsch, Adam J., "Freedom of Testation / Freedom of Contract", Minnesota Law Review, Article 95. 2180, (2011)

Howard-Hassmann, Rhoda E., "Human Security : Undermining Human Roghts?" Human Rights Quarterly, The Johns Hopkins University Press, Vol. 34 N0. 1 (2012)

Howthome, Luanda, "Contitution and Contract : "Human Digty, The Theory Capabilities and Existenzgrundlage in South Africa", Journal Studia Law Universitas Babes-Bolyai, No. 2, (2011), http:??studia.law.ubbluj,ro/articol. php?articolld=433 (diakses 23 Juni 2017)

Irakli, Tedoradze, "The Principle of Freedom of Contract, Pre-Contractual Obligations Legal Review English, EU and US Law", European Scientific Journal, Vol. 13, No. 4 (2017)

Lavdari, Irena, "The Contractual Freedom as an Essential Condition for the Existence of the Contract in a Global Economy", Mediterranean Journal of Social Sciences, Vol. 4 No. 11 (2013)

Micklitz, Hans-W., "On the Intellectual History of Freedom of Contract and Regulation", Penn State Journal of Law \& International Affairs, Vol. 4 Issue 1 (2015)

Pessers, Dorien, "The Normative Foundation of Legal Orders: A Balance Between Reciprocity and Mutuality", Netherlands Journal of Legal Philosophy 2014 (2014).

Pound, Roscoe, "Liberty of Contract", The Yale Law Journal, Vol. 18, No. 7 (May, 1909), pp. 454-487, http://www.jstor.org/stable/785551 ( diakses: 22 Juni 2017)
Schwartz, Alan dan Robert E. Scott, "Contract Theory and The Limits of Contract Law", Yale Law School Legal Scholarship Repository, (2003) : 5, http://digital commons.law.yale.edu/ lepp_ papers (diakses 27 Juli 2017)

Setiabudhi, IK. Rai, Peranan Masyarakat Sipil dalam Pemberantan Korupsi: Model Pencegahan dari Bali dalam Jurfrina Rizal dan Suhariyiono AR (ed), Demi Keadilan Antologi Hukum Pidana Dan Sistem Peradilan Pidana (Jakarta: Pustakan Kemang, 2016)

Weber, David P., "Restricting the Freedom of Contract: A Fundamental Prohibition," Yale Human Rights and Development Journal: Vol. 16: Iss. 1, Article 2 (2014)

\section{Internet}

Tom Head, "Civil Liberty", http://civilliberty.about. com/od/ internastional humanrights/g/HumanRight (diakses 1 Juli 2017)

\section{Peraturan}

Universal Declaration Human Rights Tahun 1948

Undang-Undang Dasar Negara Republik Indonesia Tahun 1945

Kitab Undang-Undang Hukum Perdata stb 1847 Nomor 23 diundangkan tanggal 30 April 1847

Undang-Undang Nomor 5 Tahun 1999 tentang Larangan Praktek Monopoli dan Persaingan Usaha Tidak Sehat

Undang-Undang Nomor 8 Tahun 1999 Nomor 42 Tentang Perlindungan Konsumen tentang Perlindungan Konsumen

Undang-Undang Nomor 39 Tahun 1999 Nomor 165 tentang Hak Asasi Manusia

Undang-Undang Nomor 12 Tahun 2005 tentang Pengesahan Komvenan Internasional Hak Sipil dan Hak Politik

Undang-Undang Nomor 12 Tahun 2011 tentang Pembentukan Peraturan Perundang-undangan 
"Halaman ini dikosongkan" 